\title{
THE DEVELOPMENT OF THE MOUSE OVARY AND ITS RESPONSE TO EXOGENOUS GONADOTROPHINS
}

\author{
P. NEAL AND S. GHALLONER \\ Hormone Laboratory, Department of Obstetrics and Gynaecology, \\ University of Edinburgh, Edinburgh EH3 $9 E R$
}

(Received 29th Fanuary 1975)

\begin{abstract}
Summary. Immature mice aged 14 to 49 days were treated with a single injection of 4 i.u. HCG, or 3 i.u. PMSG followed $48 \mathrm{hr}$ later by 2 i.u. HCG. After treatment with HCG alone the number of oocytes which were ovulated rose gradually from Day 21 to Day 28 and then remained constant, while the combined PMSG + HCG treatment induced a peak response between Days 24 and 28. The percentage of animals responding also varied with age and treatment. After the combined PMSG + HCG treatment, $90 \%$ of the animals ovulated on Day 21 , while a similar proportion was not achieved in response to HCG alone until Day 32. The variation in response with age and treatment was related to follicular development within the ovary.
\end{abstract}

\section{INTRODUCTION}

Ovulation can be induced in a number of mammals by treatment with gonadotrophic hormones (Schuetz, 1969). In mature rats and mice initial treatment with PMSG is generally followed by an ovulatory injection of HCG (Mauléon, 1969). The number of oocytes ovulated is largely determined by the strain of animal used and the dose of PMSG administered (Edwards et al., 1963; Neal \& Baker, 1974a). Ovulation can also be induced in adult mice and rats by a single injection of PMSG or HCG, ovulation occurring within $24 \mathrm{hr}$ of treatment (Burdick \& Whitney, 1941; Stern \& Schuetz, 1970; Neal \& Baker, 1973). In immature rats and mice the ovulatory response to exogenous gonadotrophic hormones is dependent not only upon the dose of hormone used but also on the age of the animal (Zarrow \& Wilson, 1961; Neal \& Baker, 1974b).

The present experiments were undertaken to examine changes within the ovaries of immature mice and to relate them to the ovulatory response to various treatments with gonadotrophins.

\section{MATERIALS AND METHODS}

Mice of the Schofield albino strain were maintained under controlled lighting (14 hr light from 05.00 hours) and temperature $\left(20^{\circ} \mathrm{C}\right)$ and given free access to Oxoid breeding diet and water. 
Animals were killed by cervical dislocation on Days 12, 14, 18, 21, 28, 36, 42 and 48 after birth (eight mice/group) and their ovaries excised. After fixation in Bouin's aqueous fluid, the tissue was dehydrated and embedded in paraffin wax. Serial sections cut at $7 \mu \mathrm{m}$ were stained with Harris's haematoxylin and eosin and examined to assess ovarian development.

Further groups of mice (20/group) were treated at various ages with a single intraperitoneal injection of 4 i.u. HCG (Pregnyl, Organon: 4 i.u. $/ 0 \cdot 1 \mathrm{ml}$ Eagle's medium $+20 \%$ calf serum) or 3 i.u. PMSG (Gestyl, Organon: 3 i.u. $/ 0 \cdot 1 \mathrm{ml}$ Eagle's medium $+20 \%$ calf serum) followed $48 \mathrm{hr}$ later by 2 i.u. HCG. All animals were killed by cervical dislocation $24 \mathrm{hr}$ after the HGG injection and their reproductive tracts were removed and examined for tubal eggs by the technique of Cunningham (1962).

\section{RESULTS}

\section{Ovarian histology}

On Day 14 the ovaries contained little intervening stromal tissue between the numerous follicles with three to four granulosa cell layers and a distinct theca (Pl. 1, Fig. 1). By the 18th day of age many follicles had enlarged and some of the largest showed antrum formation (Pl. 1, Fig. 2). A high proportion of the largest follicles contained the pyknotic granulosa cells characteristic of atretic follicles. By Days 24 to 28 the centre of the ovary had a lace-like appearance with numerous antral follicles situated around the periphery (Pl. 1, Fig. $3)$. The largest follicles had prominent thecal blood vessels and were separated by distinct stromal tissue. By Day 36 there had been a dramatic reduction in the number of large antral follicles and many follicles were atretic (Pl. 1, Fig. 4). However, there were numerous medium-sized follicles with many mitotic granulosa cells. Small groups of interstitial cells were present in the centre of the organ (PI. 1, Fig. 5). By Day 42 ovulation had occurred resulting in many CL and Graafian follicles with prominent thecal blood vessels. The amount of interstitial tissue had increased and was a prominent feature of the ovary by Day 49 (Pl. 1, Fig. 6). At this time CL were numerous, but there appeared to be fewer Graafian follicles than on Day 42.

\section{EXPLANATION OF PLATE 1}

Fig. 1. Ovary of mouse on Day 14 after birth with numerous follicles with three to five layers of granulosa cells and little intervening stromal tissue. $\times 260$.

Fic. 2. Large antral follicle (arrowed) in the ovary on Day 21. There are numerous follicles with three to four granulosa cell layers and primordial follicles are confined to the periphery of the organ. $\times 100$.

FIG. 3. Medium-sized and large antral follicles are separated by distinct stromal tissue on Day 28 . The centre of the ovary consists mainly of connective tissue and numerous prominent blood vessels (arrowed). $\times 100$.

Fig. 4. Group of follicles with pyknotic granulosa cells (P) in a mouse ovary on Day 36. Some follicles contain pyknotic and mitotic (M) cells. $\times 260$.

FIG. 5. Ovary on Day 36. The stroma is well developed in the centre of the organ and cords of interstitial cells are beginning to develop (arrowed). $\times 260$.

Fig. 6. Corpora lutea (CL) and large areas of hypertrophied interstitial tissue (IT) are prominent features of the ovary by Day 49 after birth. $\times 260$. 

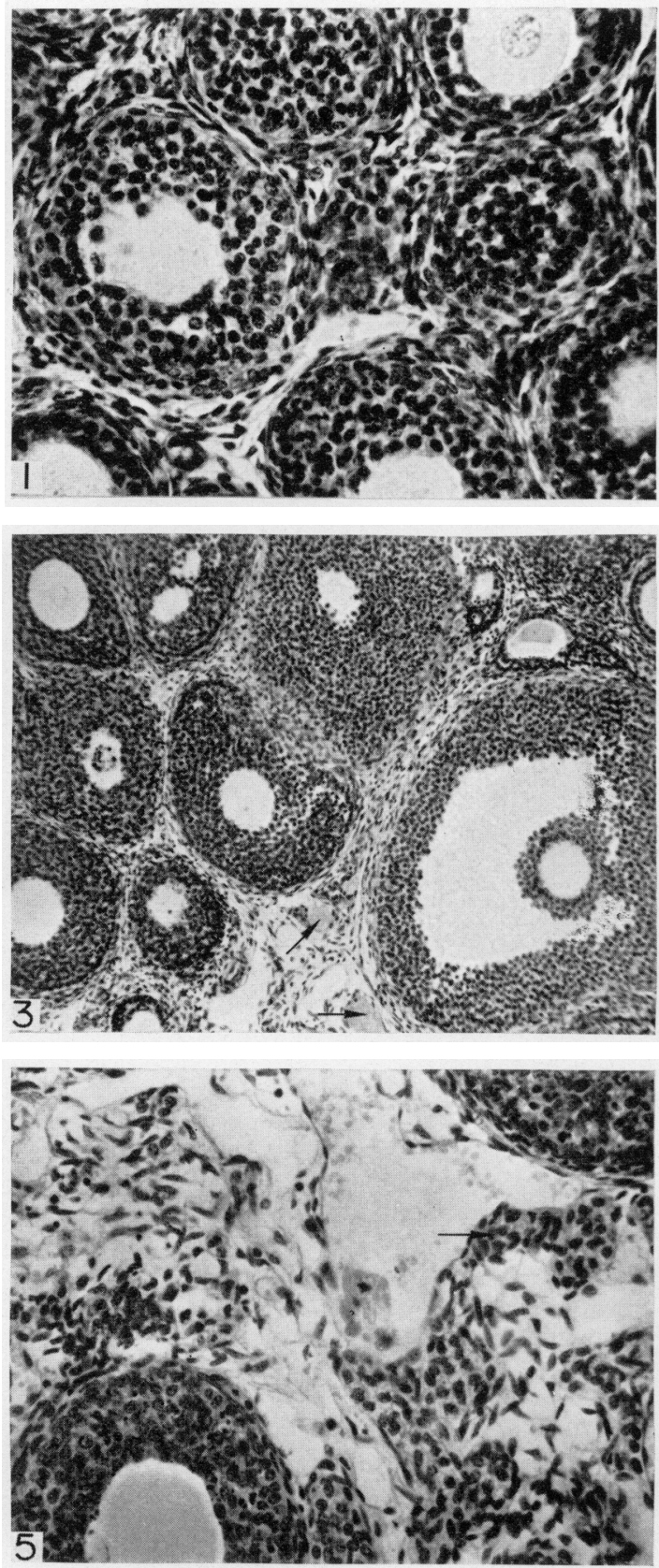
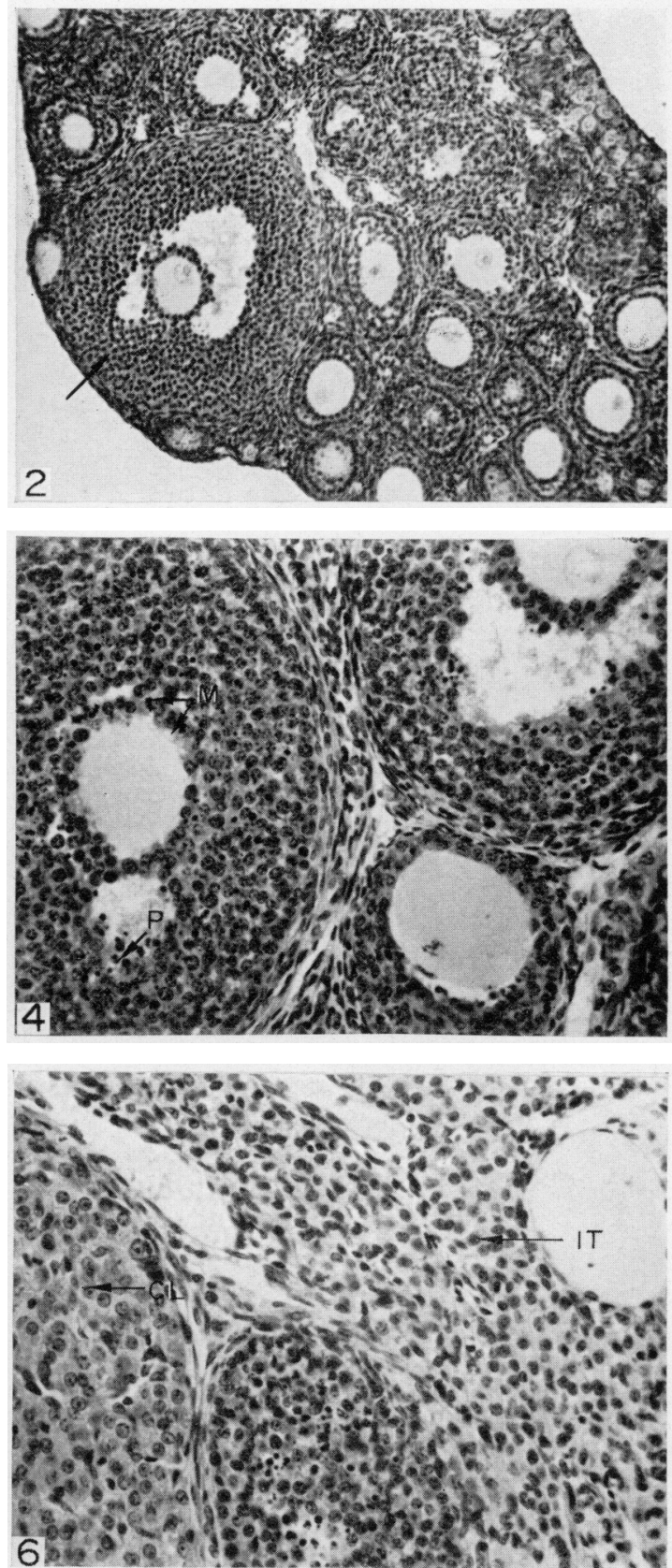


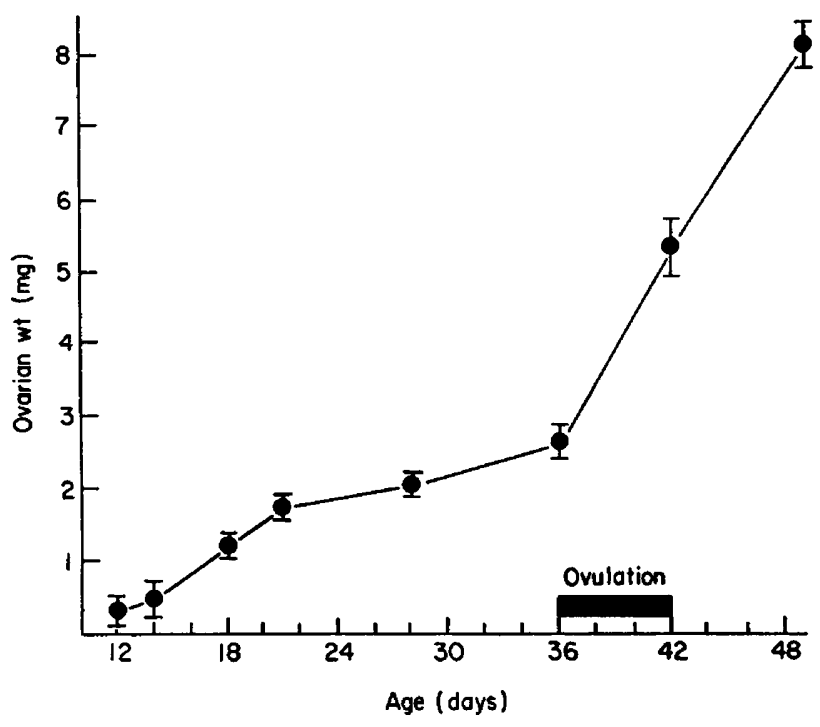

TExT-FIG. 1. Increase in the weight of the ovary of immature mice with increasing age. Values are means \pm S.E.M.

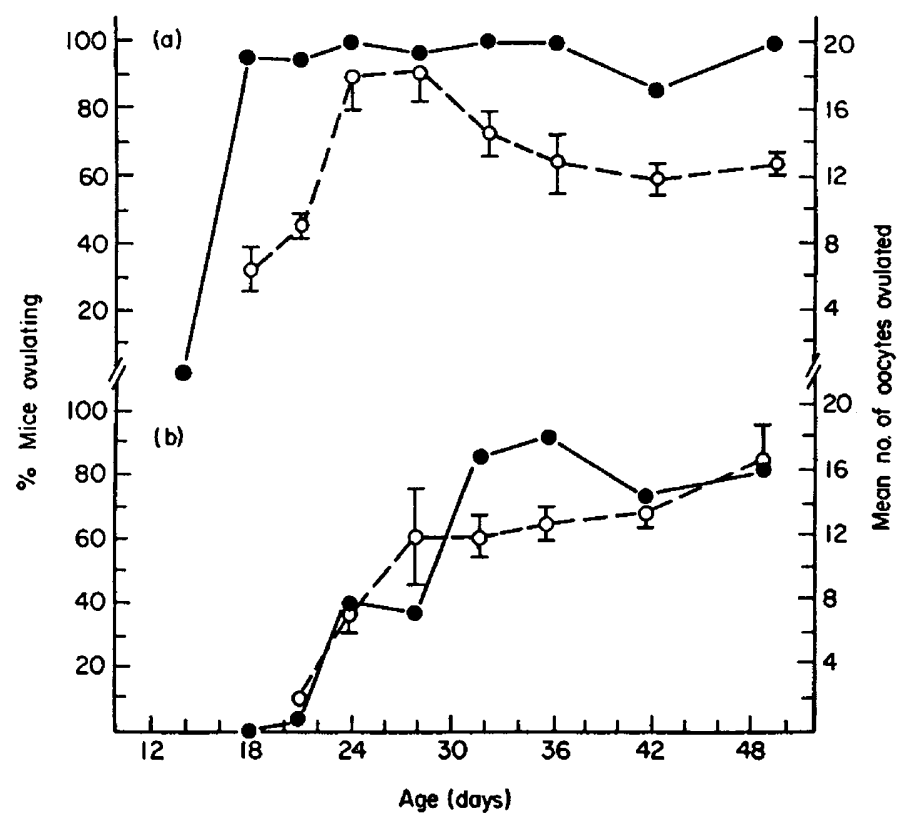

TEXT-Fig. 2. Comparative response of immature mice of various ages to (a) 3 i.u. PMSG followed 48 hr later by 2 i.u. HGG, and (b) 4 i.u. HCG only. $\bullet$, Proportion of mice ovulating; $O$, mean number of ovulations/animal responding. Values are means \pm S.E.M. 
Concurrent with the increase in the number of antral follicles was a gradual increase in the weight of the ovary (Text-fig. 1). With the onset of spontaneous ovulation (Days 36 to 42 ) the weight increased more dramatically, probably reflecting the large number of CL and hypertrophy of the interstitial tissue present at this time.

\section{Treatment with $P M S G+H C G$}

Ovulation was first induced in mice in which treatment began on Day 18. Thereafter $95 \%$ of the animals ovulated (Text-fig. 2a). This level of response was generally maintained until Day 49 although it was slightly reduced when spontaneous ovulations were also occurring. The mean number of oocytes ovulated/animal was age-dependent and increased from Day 18 to reach a peak on Days 24 to 28 , after which the number fell to that occurring at natural oestrus.

Unilateral ovulation was most frequently observed in the 18-day-old animals $(33 \%)$. Over $90 \%$ of the animals aged 24 days or more ovulated bilaterally.

\section{Treatment with HCG alone}

Ovulation was not induced by a single injection of HCG before Day 21. In older mice the proportion of animals ovulating increased with age such that, by Day $32,85 \%$ of the animals ovulated (Text-fig. $2 \mathrm{~b}$ ). The mean number of oocytes ovulated showed a similar trend rising sharply from Day 21 to Day 32 and then more slowly to Day 49 . On Day 24 all the treated animals ovulated bilaterally; by Day 32, however, the incidence of unilateral ovulations had risen to $35 \%$ before declining to $10 \%$ between Days 36 and 49 .

\section{DISCUSSION}

The response of mice to an injection of PMSG followed $48 \mathrm{hr}$ later by an ovulatory injection of HCG varied with age. At the doses of hormones used in the present study the maximum number of oocytes was ovulated between Days 24 and 28. Zarrow \& Wilson (1961) reported similar results for immature rats and mice although they used much higher doses of PMSG and HCG. The percentage of animals ovulating is less variable with age. Similar results have been reported for rats and mice (Zarrow \& Wilson, 1961; Lunn \& Loraine, 1973).

Ovulation after a single injection of HCG is the result of direct action on the ovary (De La Lastra et al., 1972) and is probably a reflection of the number of large antral follicles present in the ovary at this time (Pedersen, 1969).

The factors responsible for the large number of oocytes ovulated by mice aged 24 to 28 days in response to the combined PMSG + HCG treatment are not known, although the ovary at this time contains more medium-sized follicles than at any other time during the prepubertal period (Peters, 1969). It is probable that these follicles enlarge in response to PMSG and subsequently ovulate following exposure to HGG. The precise mechanism by which the population of follicles in the ovary is controlled is not known; hormone levels in immature mice have not been fully determined (Stiff et al., 1974). In the 
immature rat, however, in which ovarian development and response to exogenous gonadotrophins are similar to that in the mouse (Zarrow \& Wilson, 1961; Loraine \& Lunn, 1973), hormone levels have been studied (MeijsRoelofs et al., 1973a, b). At the time of maximal ovulatory response the levels of FSH and LH are low, but FSH, LH and oestradiol are at peak concentrations on approximately Day 14 and their action on the ovary at this time may account for the large number of follicles present in the ovary 7 to 14 days later. The high incidence of atretic follicles occurring after Day 24 in mice may, therefore, be indicative of the relative inadequacy of gonadotrophic hormones at this time.

The difference in the percentage of mice ovulating in response to a single injection of HCG and the combined PMSG + HCG treatment may indicate that PMSG increases not only the number of antral follicles present but also their rate of development. If PMSG merely induced the growth or maintenance of more follicles the percentage of mice ovulating would be expected to be equivalent to that occurring 2 days later following treatment with HCG alone. At 21 days of age, however, $95 \%$ of the animals responded to the combined treatment while the response to HCG alone did not approach this level until Day 32. Pedersen (1969) has shown that, in mice before Day 14 (when endogenous gonadotrophin levels are probably high; see above), more follicles begin to grow and their rate of growth is greater than at any other time during the prepubertal period. It has also been demonstrated (Pedersen, 1970) that the rate of follicular growth in the mature mouse is most rapid during oestrus following the peak FSH, LH and steroid levels associated with pro-oestrus (Ayalon et al., 1972; Murr et al., 1973).

The factors responsible for the unilateral response, which varied with age and hormone treatment, are not known. As reported previously (Falconer et al., 1961 ; McLaren, 1963; Kelly, 1971), there was no significant difference between the responses of the left and right ovaries.

It is of interest that spontaneous ovulations begin during a period in which hypertrophy of the interstitial tissue occurs and follows a period of follicular degeneration; such changes may be important in the development of ovarian cyclicity and further studies on the action of hormones on the ovary at this time are clearly necessary.

\section{ACKNOWLEDGMENTS}

This work was financed out of a grant to Dr T. G. Baker by the Population Council, New York. The hormones were provided by Organon Laboratories Ltd. We are grateful to Dr T. G. Baker for his advice and encouragement.

\section{REFERENCES}

Ayalon, D., Tsafriri, A., Lindner, H.R., Cordova, T. \& Harell, A. (1972) Serum gonadotrophin levels in pro-oestrous rats in relation to the resumption of meiosis by the oocytes. 7 . Reprod. Fert. 31, 51-58.

BURDIck, H.O. \& WhITNEy, R. (1941) Ovulation induced in mice by single injections of Follutein or untreated human pregnancy urine. Am. J. Physiol. 132, 405-410, 
Gunningham, F.J. (1962) Induction of ovulation in immature mice as an assay of gonadotrophin. $\mathcal{f}$. Endocr. 24, 215-221.

De La Lastra, M., Forcelledo, M.L. \& Serrano, C. (1972) Influence of the hypophysis on pregnant mare's serum gonadotrophin-induced ovulation in immature rats. 7 . Reprod. Fert. 31, $23-28$.

Edwards, R.G., Wilson, E.D. \& Fowler, R.E. (1963) Genetic and hormonal influences on ovulation and implantation in adult mice treated with gonadotrophin. $\mathbf{7}$. Endocr. 26, 389-399.

Falconer, D.S., Edwards, R.G., Fowler, R.E. \& Roberts, R.C. (1961) Analysis of differences in the number of eggs shed by the two ovaries of mice during natural oestrus or after superovulation. 7. Reprod. Fert. 2, 418-437.

KELLY, E.P. (1971) An examination of ovulation ratio in naturally ovulating and induced inbred and outbred mice. 7 . Reprod. Fert. 26, 271-273.

Loraine, J.A. \& LunN, S.F. (1973) The effect of initial body weight on the response of the rat to treatment with gonadotrophins. Acta endocr., Copenh. 72, 218-225.

LunN, S.F. \& Loraine, J.A. (1973) The effect of initial age on the response of the rat to treatment with gonadotrophins. Acta endocr., Copenh. 72, 209-217.

Maulton, P. (1969) Oogenesis and folliculogenesis. In Reproduction in Domestic Animals, pp. $187-215$. Eds H. Cole \& P. T. Cupps. Academic Press, New York.

Malaren, A. (1963) The distribution of eggs and embryos between sides in the mouse. $\mathcal{F}$. Endocr. 27, $157-181$.

Meijs-Roelofs, H.M.A., Uilenbroek, J.Th.J., De Jong, F.H. \& Welsahen, R. (1973a) Plasma oestradiol-17 $\beta$ and its relation to serum follicle-stimulating hormone in immature female rats. 7 . Endocr. 59, 295-304.

Meijs-Roelofs, H.M.A., Uilenbroek, J.Th.J., Osman, P. \& Welschen, R. (1973b) Serum levels of gonadotrophins and follicular growth in prepuberal rats. In The Development and Maturation of the Ovary and its Functions, pp. 3-11. Ed. H. Peters. Excerpta Medica, Amsterdam.

Murr, S.M., Geschwind, I.I. \& Bradford, G.E. (1973) Plasma LH and FSH during different oestrous cycle conditions in mice. F. Reprod. Fert. 32, 221-230.

NeAL, P. \& BAKer, T.G. (1973) Response of mouse ovaries in vivo and in organ culture to pregnant mare's serum gonadotrophin and human chorionic gonadotrophin. I. Examination of critical time intervals. 7. Reprod. Fert. 33, 399-410.

Neal, P. \& BAKer, T.G. (1974a) Response of mouse ovaries in vivo and in organ culture to pregnant mare's serum gonadotrophin and human chorionic gonadotrophin. II. Effect of different doses of hormones. 7. Reprod. Fert. 37, 399-404.

Neal, P. \& BAKer, T.G. (1974b) Response of mouse ovaries in vivo and in organ culture to pregnant mare's serum gonadotrophin and human chorionic gonadotrophin. III. Effect of age. $\mathcal{F}$. Reprod. Fert. 39, $411-414$.

Pedersen, T. (1969) Follicle growth in the immature mouse ovary. Acta endocr., Copenh. 62, $117-132$.

Pedersen, T. (1970) Follicle kinetics in the ovary of the cyclic mouse. Acta endocr., Copenh. 64, $304-323$.

Peters, H. (1969) The development of the mouse ovary from birth to maturity. Acta endocr., Copenh. 62, 98-116.

Schuetz, A.W. (1969) Oogenesis: processes and their regulation. Adv. Reprod. Physiol. 41, 99-148.

Stern, S. \& Schuetz, A.W. (1970) Asynchrony of ovulation and mating in mice treated with gonadotrophins. 7. Reprod. Fert. 23, 257-261.

Stiff, M.E., Bronson, F.H. \& Stetson, M.H. (1974) Plasma gonadotrophins in prenatal and prepubertal female mice: disorganization of pubertal cycles in the absence of a male. Endocrinology 94, $492-496$.

ZaRrow, M.X. \& Wilson, E.D. (1961) The influence of age on superovulation in the immature rat and mouse. Endocrinology 69, 851-855. 